\title{
A silent killer in the Far North Region of Cameroon: Increasing prevalence of hypertension among Kaele dwellers
}

Françoise Raïssa Ntentie*1,2, Boris Ronald Tonou Tchuente ${ }^{2}, 3$, Maxwell Wandji Nguedjo ${ }^{2}, 3$, Gérald Dama1, Ousmane Mfopou Mboindi², Boris Gabin Kingue Azantsa ${ }^{2}$, Judith Laure Ngondi 2 and Enyong Julius Oben²

\footnotetext{
${ }^{1}$ Department of Earth and life Sciences, Higher Teachers' Training College, University of Maroua, Maroua, Cameroon.

${ }^{2}$ Laboratory of Nutrition and Nutritional Biochemistry, Department of Biochemistry, University of Yaounde 1, Yaounde, Cameroon.

${ }^{3}$ Centre for Food and Nutrition Research, Institute of Medical Research and Medicinal Plants study, Ministry of Scientific Research and Innovation, Yaounde, Cameroon.

*Corresponding Author Email : franc_ntentie@yahoo.fr
}

Hypertension (HTN) is the major risk factor of cardiovascular diseases. Its prevalence is still in perpetual increase worldwide. The aim of this study was to evaluate the prevalence and risk factors of HTN among Kaele dwellers, in the Far North Region of Cameroon where less attention seems to be paid on awareness and sensitization against overnutrition related diseases. Two hundred and four participants were recruited during free health campaign on cardiovascular diseases organized from $10-15^{\text {th }}$ February 2017 in Kaele. Anthropometric and clinical parameters (weight, height, waist circumference, body mass index, blood pressure and heart rate) were measured. A blood sampling was collected for lipid profile analysis. HTN and sub-types were diagnosed according to World Health Organization (WHO) and International Diabetes Federation (IDF) definitions respectively meanwhile hypercholesterolemia and hypertriglyceridemia were diagnosed with IDF criteria. The overall prevalence of the HTN was $\mathbf{2 9 . 9 \%}$. Men were more affected than women (35\% vs $22.6 \%, p<0.05)$. Participants aged between $50-59$ years and $>60$ years were more affected $(p<0.05)$. Forty-one percent $(41 \%)$ of the hypertensive subjects of the study had systo-diastolic sub-type of HTN meanwhile $36.1 \%$ had isolated systolic HTN vs $23 \%$ with isolated diastolic HTN. Risk factors associated to HTN were : male gender (OR=2.236; $\mathrm{p}<0.05)$; absence of education $(\mathrm{OR}=24.296$; $\mathrm{p}<0.05)$; primary education level (OR=1.933; $p<0.05)$; marital status "married" ( $O R=3.117 ; p<0.05)$, increased age $(30-39,50-59$, and $>60$ years, respectively with $0 R=4.113$, $p<0.05$; $0 R=31.405, p<0.05$ and $0 R=18.694, p<0.05$ ), abdominal obesity $(\mathrm{OR}=2.476 ; \mathrm{p}<0.05)$ and low milky products consumption $(\mathrm{OR}=2.031$, $\mathbf{p}<0.05)$. HTN is quite present in Kaele locality and many non-modifiable, modifiable and socio-economic risk factors significantly contributed to its development.
\end{abstract}

Key words: HTN, prevalence, risk factors, kaele, cameroon.

\section{INTRODUCTION}

Non-communicable diseases represent a heavy burden at the global scale and constitute the first cause of death worldwide (WHO, 2015). According to WHO statistics, those diseases are responsible for $68 \%$ of 56 million deaths worldwide. In Africa, there is an important increase of their prevalence and this situation causes, not only a big deficit in the budget of the states or families, but also impairs the health quality of individuals. Amongst these diseases, hypertension (HTN) is the most frequent (Sliwa et al., 2011; Mohsen and Damasceno, 2012). HTN is a chronic disease 
characterize by progressive and permanent increase of blood pressure (BP). It is also called 'silent killer' due to the frequent occurrence of major complications and deaths in patients presenting high blood pressures figures without any clinical signs. HTN causes severe damages to brain, heart, kidney and sometimes premature death when not treated (Koopman et al., 2012). It is the major cause of 50\% of heart disease, stroke and heart failure. It is also involved in over $40 \%$ of deaths in those with diabetes and increase the risk for foetal and maternal death during pregnancy, as well as for dementia and renal failure (Lim et al., 2013; Campbell et al,. 2014). According to WHO (2011) 30 to 50\% of deaths were attributed to HTN in developing countries. In Sub-Saharan African (SSA) countries, the prevalence is increasing (Campbell et al,. 2014) and the overall prevalence was estimated at $16.2 \%$ (95\% CI $14.2 \%$ to $20.3 \%$ ) with an estimated number of hypertensive individuals to be 74.7 million. It is projected that the number of affected individuals will increase by $68 \%$ (125.5 million) by 2025 (Ogah and Rayner, 2013). This increase prevalence is mostly due to the rapid urbanization and industrialization (Hendriks et al., 2012) and also by mass migration of rural Africans to urban areas. As part of SSA countries, the prevalence of HTN still in perpetual increase in Cameroon. One third of adults have high blood pressure (Kingue et al., 2015). The prevalence of HTN is reported to vary from $31.1 \%$ in rural milieu (Arrey et al., 2016), 32.2\% in semi-urban (Ntentie et al., 2014) to $47.5 \%$ in urban milieu (Dzudie et al., 2012) with a national average of $31.0 \%$ (Kingue et al., 2015). In our context, because most of patients are unaware of their disease, the increasing prevalence of hypertension is associated with an important proportion of target organ damage at diagnosis (Gnindjio et al., 2018). Given the fact that most of these damages are irreversible and associated with substantial morbidity and mortality, many projects and studies have been initiated in order to prevent, or delay the expansion of HTN and its complications among population. But those projects are mostly in favour of population of the Southern Regions of the Country meanwhile those of the Northern part of the country are no more concern. This situation is because the Northern part of the country is known to be facing undernutrition related problems (food insecurity and micronutrient deficiencies) (Ndedi, 2017 ; Tanankem and Fotio, 2016 ; Cumber et al., 2017) forgetting that the overall Cameroonian population have already stated nutritional transition process (Ntentie et al., 2014). So far, referenced studies carried in the Northern Regions are restricted to headsquares of Region (Ngaoundéré and Maroua) and were done only in the hospital milieu (Pancha et al., 2011; Pancha et al., 2015; Pancha et al., 2016 ; Tebeu et al., 2011). Thus, there is a need to describe and analyze HTN patterns and its risk factors. This, in order to fill the gap of data and also to contribute in the development of preventive and management policies to reduce the expansion of the pathology and its complications in this part of the Country. Therefore, the present study has been initiated and aimed at assessing the prevalence of HTN and identifying the risk factors specific to population living in Kaele, a locality of the Mayo Kani Division in the Far North Region of Cameroon.

\section{MATERIAL AND METHODS}

\section{Description of study area and population}

A cross-sectional and descriptive survey was conducted from $10^{\text {th }}$ to $15^{\text {th }}$ February 2017 in Kaele, head quarter of the Mayo Kani Division in the Far North Region of Cameroon. The sampling was randomized and involved four towns: Gouzougoui, Kililimbri, Djidoma and Lara. A total of 204 apparently healthy participants aged 18 years and above were recruited during the health campaign organized by the Cameroon Nutritional Science Society on good nutritional practices.

\section{Ethical considerations}

The study protocol was approved by the National Ethics Committee $\mathrm{N}^{\circ}$ 2014/08/488/EC/CNERSH and was conducted in strict compliance with the physical, moral and psychological integrity of all participants; following the principles outlined in the Helsinki Declaration.

\section{Questionnaire}

Data were collected using a questionnaire adapted from WHO STEPwise approach for chronic disease risk factor surveillance - Instrument v2.1. This questionnaire included informations on residence in Kaele (at least one year), smoking and alcohol consumption. Fruits, vegetables, meat, fish and milk intake were assessed by self-report under the assistance of well trained investigators. Alcohol consumption was classified into two categories: abstainers (never consumed) and occasional (drank in the past 12 months) or daily drinkers. Smoking included: manufactured or hand-rolled cigarettes, cigars, smoked, chewed or inhaled products. Participants were classified as abstainers or smokers. Fruits, vegetables, meat, fish, dairy products intake was based on the frequency of intake per week. From 0-1 time per week, intake was classified as low; 2-3 times/week as moderate and 4 to 7 times/week as high. The level of education, marital status, source of income, personal and family history of HTN were also assessed.

\section{Anthropometric measurements, evaluation of nutritional status and abdominal obesity}

Weight, height, waist circumference were measured on participants in light clothing, without shoes and motionless according to standard methods. Body Mass Index (BMI), were computed and categorized according to WHO (2003) criteria where a BMI $<18.5 \mathrm{~kg} / \mathrm{m}^{2}$ is considered as underweight; BMI range $18,5-25 \mathrm{~kg} / \mathrm{m}^{2}$ as normal, from 25 to $29 \mathrm{~kg} / \mathrm{m}^{2}$ individual was considered as overweight, and a $\mathrm{BMI} \geq 30 \mathrm{~kg} / \mathrm{m}^{2}$ was referred to as obesity. Abdominal 
Table 1. Classification of Blood pressure in Adults (age $\geq 18$ years). (Update JNC-8 Guidelines recommandations)

\begin{tabular}{|c|c|c|c|}
\hline & Systolic BP (mmHg) & and/or & Diastolic BP (mmHg) \\
\hline Normal & $\leq 129$ & & $\leq 84$ \\
\hline prehypertension & $130-139$ & & $85-89$ \\
\hline Stage 1 HTN & $140-159$ & & $90-99$ \\
\hline Stage 2 HTN & $\geq 160$ & & $\geq 100$ \\
\hline
\end{tabular}

obesity was diagnosed using IDF (2005) criteria (waist circumference $\geq 80 \mathrm{~cm}$ for women and $\geq 94 \mathrm{~cm}$ for men).

\section{Blood pressure measurement and HTN definition}

Blood pressure was measured on seated participant thrice on the right arm at five minutes interval; with uncrossed legs using an Automatic Digital Blood Pressure Arm Monitor SMARTHEART ${ }^{\mathrm{TM}}$ manufactured for Veridian Healthcare 1175 Lakeside Drive Gurnee, IL 60031 USA, made in China. Mean blood pressure of three closest measures was obtained. Hypertension was diagnosed using two definitions: WHO (1999) (Systolic Blood Pressure (SBP) $\geq 140 \mathrm{mmHg}$ and/or Diastolic Blood Pressure (DBP) $\geq 90 \mathrm{mmHg}$ ) and IDF (2005) [23] (SBP $\geq 130 \mathrm{mmHg}$ and/or DBP $\geq 85 \mathrm{mmHg}$ ). Hypertension subtypes were referred as per Franklin et al. (2005) criteria which diagnosis include Isolated Systolic Hypertension (ISH) for a SBP $\geq 130$ and DBP $<85 \mathrm{mmHg}$; Isolated Diastolic Hypertension (IDH) for a $\mathrm{SBP}<130$ and $\mathrm{DBP} \geq 85 \mathrm{mmHg}$ and the Systo-Diastolic Hypertension (SDH) with a SBP $\geq 130$ and DBP $\geq 85 \mathrm{mmHg}$. To classify hypertensive participants according to the grade of illness, the Joint National Committee 8 (JNC-8) criteria were used as presented in Table 1.

\section{Blood sampling, biochemical analysis and diagnostic of hyperlipidemia}

Blood sampling was done in the morning after a 10-hour overnight fasting. About $4 \mathrm{ml}$ of venous blood was collected on EDTA tubes by venipuncture in the hand of each participant. The plasma was obtained by centrifugation and aliquots were frozen at $-20^{\circ} \mathrm{C}$ for further biochemical analyses. As biochemical analysis, total cholesterol and triglycerides levels were measured with standard enzymatic spectrophotometric method using ChronoLab Diagnostic Kits in the laboratory provided by CHRONOLAB SYSTEMS, S.L., C/Diputación 260, 08007 Barcelona, SPAIN. IDF (2006) criteria were used to diagnose hypercholesterolemia (total cholesterol level $\geq 200 \mathrm{mg} / \mathrm{dL}$ ) and hypertriglyceridemia (triglycerides level $\geq 150 \mathrm{mg} / \mathrm{dL}$ ).

\section{Data management and statistical analysis}

Data were analyzed using SPSS 16.0 for Windows. Descriptive analysis results were presented as means \pm standard deviations for continuous variables and as frequencies for categorial variables. Student $t$ test and Chi square test were performed to compare continuous and categorial variables, respectively. Pearson correlation was performed to state the linear correlations between blood presure and some anthropometric and biochemical parameters. Whereas binary logistic regressions were used to evaluate the relative risk of HTN with statistical significance at $\mathrm{p}<0.05$.

\section{RESULTS}

\section{Baseline Characteristics}

As shown in Table 2, the study population was constituted of $58.8 \%$ male (120) and $41.2 \%$ female (84). Ten point three percent amongst women were menopausal $(n=21)$. Concerning the marital status, there was $39.7 \%(\mathrm{n}=81)$ married, $56.4 \%$ (115) single and $3.9 \%$ (8) widowed or divorced. Participants were mostly from the Moundang ethnic group $87.7 \%$ (179), 3.9\% (8) were Toupouri, 3.9\% (8) were Guiziga and 4.4\% (9) from other minor ethnic groups living in Kaele locality. 8.4\% (17) were illiterates (no education level), 24.6\% (50) had a primary level of education and $67 \%$ (137) were up to secondary school. According to nutritional status, $75 \%$ (153) participants were normal weight, $14.7 \%$ (30) were underweight and only $10.3 \%$ (11) were overweight or obese. Exploration of food habits and lifestyle revealed a high proportion of alcohol consumers $(61.8 \%$; $n=126)$ as well as fruits, vegetables, fish, meat and dairy product consumption.

Anthropometric and hemodynamic parameters of the study population (Table 3) revealed that, according to gender, only systolic blood pressure was significantly higher among male $(129.78 \pm 21.79 \mathrm{mmHg})$ compared to female $(120.64 \pm 22.76 \mathrm{mmHg})$ meanwhile heart rate $(\mathrm{p}<0.05)$ was higher among female $(83.33 \pm 13.44$ Pulse/min).

\section{Prevalence and characteristic of HTN in Kaele}

As presented in Table 4, 29.9\% ( $\mathrm{n}=61)$ of participants were hypertensive according to WHO criteria and male were most affected (35\%; $n=42)$ than female $(22.6 \% ; n=19)$ $(\mathrm{p}<0.05)$. The results also revealed an important proportion of prehypertensive subjects $(18.6 \%)$ in the 
Int. Res. J. Med. Biomed. Sci.

Table 2. Description of the study population

\begin{tabular}{|c|c|c|c|}
\hline Characteristic & Categories & Frequency $(\mathrm{N}=204)$ & Percentage (\%) \\
\hline \multirow[t]{2}{*}{ Gender } & Male & 120 & 58.8 \\
\hline & Female & 84 & 41.2 \\
\hline \multirow[t]{3}{*}{ Marital status } & Married & 81 & 39.7 \\
\hline & Single & 115 & 56.4 \\
\hline & Divorced/widowed & 8 & 3.9 \\
\hline \multirow[t]{3}{*}{ Level of education } & Illiteracy & 17 & 8.4 \\
\hline & Primary school & 50 & 24.6 \\
\hline & Secondary school & 137 & 67 \\
\hline \multirow[t]{4}{*}{ Ethnic group } & Moundang & 179 & 87.7 \\
\hline & Toupouri & 8 & 3.9 \\
\hline & Guiziga & 8 & 3.9 \\
\hline & Others & 9 & 4.4 \\
\hline \multirow[t]{3}{*}{ Income source } & Permanent & 14 & 6.9 \\
\hline & Temporary & 30 & 14.7 \\
\hline & Assistance/help & 160 & 78.4 \\
\hline \multirow[t]{4}{*}{ BMI } & Underweight & 30 & 14.7 \\
\hline & Normal & 153 & 75 \\
\hline & Overweight & 18 & 8.8 \\
\hline & obese & 3 & 1.5 \\
\hline Family history of HTN & yes & 16 & 7.9 \\
\hline Alcohol & yes & 126 & 61.8 \\
\hline Tobacco & yes & 9 & 4.4 \\
\hline Fruits consumption & yes & 168 & 83.2 \\
\hline Green vegetable consumption & yes & 203 & 99.5 \\
\hline Meat consumption & yes & 199 & 97.5 \\
\hline Fish & yes & 200 & 98 \\
\hline Diary products consumption & yes & 111 & 54.4 \\
\hline
\end{tabular}

Table 3. Anthropometric and hemodynamic characteristics of the study population

\begin{tabular}{lccc}
\hline Parameters & Population & Female & Male \\
\hline Age (years) & $34.16 \pm 17.18$ & $36.02 \pm 17.87$ & $32.85 \pm 16.63$ \\
BMI (kg/m²) & $21.40 \pm 3.20$ & $21.79 \pm 3.98$ & $21.12 \pm 2.49$ \\
Waist circumference (cm) & $78.78 \pm 11.25$ & $78.34 \pm 11.62$ & $79.09 \pm 11.02$ \\
SBP (mmHg) & $126.02 \pm 22.60$ & $120.64 \pm 22.76$ & $129.78 \pm 21.79^{*}$ \\
DBP (mmHg) & $80.82 \pm 12.76$ & $78.80 \pm 11.99$ & $82.22 \pm 13.14$ \\
Heart rate (Pulse/min) & $78.96 \pm 13.74$ & $83.33 \pm 13.44$ & $75.87 \pm 13.14^{*}$ \\
\hline
\end{tabular}

*Significantly different between male and female at $\mathrm{p}<0.05$ with student $\mathrm{t}$ test. BMI: Body Mass Index, SBP: systolic blood pressure; DBP: diastolic blood pressure

study population. Most hypertensive participants suffering from combined systo-diastolic subtype, except among female were most of them presented isolated systolic subtype. The overall prevalence also increased with age.

\section{HTN and other cardiometabolic risk factors}

The relationship between HTN and other cardiometabolic risk factors such as overweight, abdominal obesity, hypercholesterolemia and hypertriglyceridemia were evaluated (Table 5 and 6). The Pearson correlation between $\mathrm{BP}$ and some anthropometric and lipid parameters revealed a positive correlation between BMI and SBP ( $\mathrm{r}=0.139$; $\mathrm{p}=0.048)$ or DBP $(\mathrm{r}=0.181 ; \mathrm{p}=0.010)$; and between waist circumference and SBP ( $\mathrm{r}=0.265 ; \mathrm{p}=0.0001)$ (Table 5). These observations were also confirmed by the significant higher waist circumference $((81.33 \pm 10.04 \mathrm{~cm} ; \mathrm{p}=0.004))$ or BMI $\left(21.85 \pm 3.66 \mathrm{~kg} / \mathrm{m}^{2} ; \mathrm{p}=0.049\right)$ among hypertensive group compared to non hypertensive individuals and also by a significantly high prevalence of hypertensive subjects with abdominal fat accumulation (Table 6). For lipid disorders, no significant difference was observed between hypertensive and non hypertensive individuals (Table 6) as well as no relationship between BP level and lipidic parameters (Table 5). But regardless of the prevalence of hyperlipidemia, the results on Table 6 shows that the number of subjects with hypercholesterolemia $(n=03$; $3.3 \%)$ and hypertriglyceridemia $(n=6 ; 6.7 \%)$ was higher 
Table 4. Prevalence and characteristic of HTN in the study population

\begin{tabular}{|c|c|c|c|c|}
\hline & & Population \% (n) & Female \% (n) & Male \% (n) \\
\hline \multirow[t]{2}{*}{ Diagnostic criteria } & WHO & $29.9(61)$ & $22.6(19)^{*}$ & $35(42)$ \\
\hline & IDF & $48.6(99)$ & $36.1(31)^{*}$ & $56.7(68)$ \\
\hline \multirow[t]{3}{*}{ HTN stage } & PreHTN & $18.6(38)$ & $13.4(12)$ & $21.7(26)$ \\
\hline & Stage 1 & $16.2(33)$ & $14.3(12)$ & $17.5(21)$ \\
\hline & Stage 2 & $13.8(28)$ & $8.4(7)$ & $17.5(21)$ \\
\hline \multirow[t]{3}{*}{ Subtypes } & Isolated diastolic HTN & $23(14)$ & $15.8(3)$ & $26.2(11)$ \\
\hline & Isolated systolic HTN & $36.1(22)$ & $47.4(9)$ & $31(13)$ \\
\hline & Systo-diastolic HTN & $41(25)$ & $36.8(7)$ & $42.9(18)$ \\
\hline \multirow{5}{*}{$\begin{array}{l}\text { Age strata } \\
\%(n / N)\end{array}$} & 18-29 years & $30.8(37 / 120)$ & $8.9(4 / 45)$ & $44(33 / 75)$ \\
\hline & 30-39 years & $64.7(11 / 17)$ & $66.7(4 / 6)$ & $63.6(7 / 11)$ \\
\hline & 40-49 years & $50(12 / 24)$ & $27.3(3 / 11)$ & $69.2(9 / 13)$ \\
\hline & 50-59 years & $93.3(14 / 14)$ & $90.9(10 / 11)$ & $100(4 / 4)$ \\
\hline & $\geq 60$ years & $89.3(25 / 28)$ & $90.9(10 / 11)$ & $88.2(15 / 17)$ \\
\hline
\end{tabular}

*significantly different between male and female at $\mathrm{p}<0.05$ with Chi square test

Table 5. Pearson correlation between blood presure level and some anthropometric and lipid parameters

\begin{tabular}{llcccc}
\hline & & BMI & Waist circumference & Total cholesterol & Triglycerides \\
\hline SBP & Correlation coefficient $r$ & 0.139 & 0.265 & 0.137 & 0.054 \\
& P value & 0.048 & 0.0001 & 0.060 & 0.458 \\
DBP & Correlation coefficient $r$ & 0.131 & 0.181 & 0.066 & 0.043 \\
& P value & 0.062 & 0.010 & 0.366 & 0.555 \\
\hline
\end{tabular}

Table 6 . Relation between other cardiometabolic risk factors and HTN

\begin{tabular}{|c|c|c|c|c|}
\hline & $\begin{array}{c}\text { Population } \\
(\mathrm{N}=190)\end{array}$ & $\begin{array}{l}\text { Hypertensive } \\
(\mathrm{N}=55)\end{array}$ & $\begin{array}{l}\text { Normal } \\
(\mathrm{N}=135)\end{array}$ & P value \\
\hline Cholesterol (mg/dL) & $116.38 \pm 34.46$ & $120.62 \pm 41.02$ & $112.55 \pm 26.91$ & 0.107 \\
\hline Triglycerides (mg/dL) & $76.42 \pm 46.50$ & $77.48 \pm 45,95$ & $75.46 \pm 47.20$ & 0.765 \\
\hline BMI $\left(\mathrm{kg} / \mathrm{m}^{2}\right)$ & $21.40 \pm 3.20$ & $21.85 \pm 3,66$ & $20.97 \pm 2.63$ & 0.049 \\
\hline Waist circumference $(\mathrm{cm})$ & $78.78 \pm 11.25$ & $81.33 \pm 10,04$ & $76.43 \pm 11.84$ & 0.004 \\
\hline Hypercholesterolemia (Chol $\geq 200 \mathrm{mg} / \mathrm{dL})(\%(\mathrm{n}))$ & $1.6(3)$ & $3.3(3)$ & $0(0)$ & 0.066 \\
\hline Hypertriglyceridemia (TAG $\geq 150 \mathrm{mg} / \mathrm{dL})(\%$ (n)) & $4.2(8)$ & $6.7(6)$ & $2.0(2)$ & 0.110 \\
\hline Overweight (BMI $\left.\geq 25 \mathrm{~kg} / \mathrm{m}^{2}\right)(\%(\mathrm{n}))$ & $10.3(21)$ & $13.1(13)$ & $7.6(8)$ & 0.195 \\
\hline Abdominal fat distribution (\% (n)) & $23.1(40)$ & $31.3(26)$ & $15.6(14)$ & 0.014 \\
\hline
\end{tabular}

Chol: Cholesterol; TAG: Triglycerides.Results are expressed as means \pm Standard deviation for lipid blood level, BMI and Waist and as \% (n) for hyperlipidemia, overweight and abdominal fat distribution

among hypertensive group compared to non hypertensive individuals.

\section{Influence of some risk factor on the incidence of high blood pressure in the study population}

Table 7 shows gender influence on blood pressure elevation. It appears that men were 2.2 times more exposed to elevated blood pressure than women. Regarding the level of education, those with no education were 24.3 times more likely to be at risk of high blood pressure (HBP), and those with primary education level were 1.9 times more likely to suffer hypertension than those with a secondary education level. For marital status, "married" individuals increased by 3.1 times the risk of HTN compared to "single" individuals. With respect to age, individuals aged 30-39, 5059, 60 and older were respectively 4.1 times; 31.4 times and 18.7 times more at risk of high blood pressure than the younger ones. Regarding the consumption of dairy products, those who did not consume them were 2 times more exposed to hypertension. Another important fact was the increased risk of HTN (2.4 times) with the presence of abdominal fat distribution $(\mathrm{p}<0.05)$.

\section{DISCUSSION}

The prevalence of HTN observed in Kaele locality (29.9\%) 
Int. Res. J. Med. Biomed. Sci.

Table 7. Odd ratio of elevated blood pressure according to some modifiable and non-modifiable risk factors

\begin{tabular}{|c|c|c|c|}
\hline & & Odd ratio (CI 95\%) & p value \\
\hline \multirow[t]{2}{*}{ Gender } & Female & 1 & \\
\hline & Male & $2.236(1.262-3.960)$ & 0.006 \\
\hline \multirow[t]{3}{*}{ Education level } & Secondary & 1 & \\
\hline & Illiteracy & $24.296(3.130-188.595)$ & 0.002 \\
\hline & Primary & $1.933(1.003-3.723)$ & 0.049 \\
\hline \multirow[t]{3}{*}{ Marital status } & Single & 1 & \\
\hline & Married & $3.117(1.724-5.633)$ & 0.0001 \\
\hline & Widowed/divorced & $2.897(0.659-12.736)$ & 0.159 \\
\hline \multirow[t]{5}{*}{ Age (years) } & $18-29$ & 1 & \\
\hline & $30-39$ & $4.113(1.414-11.960)$ & 0.009 \\
\hline & $40-49$ & $2.243(0.922-5.457)$ & 0.075 \\
\hline & $50-59$ & $31.405(3.981-247.745)$ & 0.001 \\
\hline & 60 and above & $18.694(5.310-65.816)$ & 0.0001 \\
\hline \multirow[t]{3}{*}{ Income source } & Permanent & 1 & \\
\hline & Temporary & $1.006(0.324-3.124)$ & 0.992 \\
\hline & Assistance/help & $0.466(0.149-1.452)$ & 0.188 \\
\hline \multirow[t]{2}{*}{ Overweight } & no & 1 & \\
\hline & yes & $1.833(0.725-4.633)$ & 0.200 \\
\hline \multirow{2}{*}{$\begin{array}{l}\text { Abdominal fat } \\
\text { accumulation }\end{array}$} & no & 1 & \\
\hline & yes & $2.476(1.187-5.164)$ & 0.016 \\
\hline \multirow[t]{2}{*}{ Alcohol consumption } & no & 1 & \\
\hline & yes & $1.632(0.922-2.889)$ & 0.093 \\
\hline \multirow[t]{2}{*}{ Tobacco use } & no & 1 & \\
\hline & yes & $3.918(0.794-19.339)$ & 0.094 \\
\hline \multirow[t]{2}{*}{ Fruits consumption } & yes & 1 & \\
\hline & no & $0.717(0.340-1.513)$ & 0.382 \\
\hline \multirow[t]{2}{*}{ Vegetables consumption } & yes & 1 & \\
\hline & no & / & / \\
\hline \multirow[t]{2}{*}{ Meat consumption } & no & 1 & \\
\hline & yes & $0.701(0.115-4.286)$ & 0.701 \\
\hline \multirow[t]{2}{*}{ Fish consumption } & yes & 1 & \\
\hline & no & $0.347(0.035-3.392)$ & 0.363 \\
\hline \multirow{2}{*}{$\begin{array}{l}\text { Dairy products } \\
\text { consumption }\end{array}$} & yes & 1 & \\
\hline & no & $2.031(1.160-3.554)$ & 0.013 \\
\hline
\end{tabular}

was lower than that $31.0 \%$ noted by Kingue et al. (2015) in Cameroon. This difference could be explained by the fact that Kaele is a less urbanized area and studies shown that urbanization increases the risk of chronic diseases (Ramachandran et al., 2008). In the general population, the systo-diastolic subtype was $41 \%$ followed by isolated systolic hypertension subtype (36.1\%). In women, isolated systolic HTN was the dominant subtype (47.4\%), while among men, systo-diastolic HTN was the most prevalent $(42.9 \%)$. The results obtained were different to those of Azantsa et al. (2010 and 2013) who noted that the isolated diastolic subtype was more common in Cameroonian obese and metropolis dwellers, respectively. The lower percentage of isolated diastolic HTA obtained in our study (23\%) compared to that obtained by Azantsa et al. (2010) $(32.8 \%)$, would be attributed to the lower degree of urbanization of the city of Kaele compared to the metropolis Yaounde. In fact, the lifestyle of urban population are risk factors for high blood pressure (sedentary lifestyle, high consumption of alcohol ...) (Maire et al., 2002). In addition, this isolated diastolic subtype is strongly correlated with obesity; which was not the case among Kaele dwellers with only $10.3 \%$ overweight (Table 6). The significant difference between male and female HTA found in this study (Table 4) was consistent with most published data in Africa and elsewhere in the world (Rabarijaona et al., 2009; Ghadhban and Habib, 2011; Seed et al., 2011). However, it should be noted that in some countries, the prevalence has been higher among women (WHO, 2013). Indeed, HTN is more common in men before age 50, thereafter, the trend is reversed (Lloyd-Jones et al., 2010). In fact, ovarian hormones, especially estrogens (Hilliard et al., 2013a), appear to play an important protective role through the modulation of the reninangiotensin-aldosterone system (Hilliard et al., 2013b), an effect on cardiovascular function via their kidneys, heart, vascular system and even the central nervous system (Xue et al., 2013). Women would therefore be much more protected against HTN before menopause (WHO, 1996).

Only $10.2 \%$ of the women in this study were menopausal, 
hence the higher prevalence among men.

Exploration of relationship between high blood pressure and some biochemical parameters (Table 5-6) revealed no significant difference of lipid profile between normal participants and those with elevated blood pressure meaning that HTN is not a matter of lipid abnormalities in this population, but the presence of such situation can contribute to increase the incidence of HTN among Kaele inhabitants according to mechanisms described by many studies (Halperin et al., 2006; Otsuka et al., 2016). In fact, atherogenic lipid abnormalities clearly cause endothelial dysfunction possibly through impaired nitric oxide production and activity, as well as alterations in endothelin1, endothelin A and B receptor expression. The endothelial dysfunction could lead to an inability or difficulty in vasodilatation to appropriate stimuli and eventually to increased resting blood pressure (Oparil et al., 2003).

An important finding of the present study was the high risk of elevated blood pressure among subjects with abdominal fat accumulation (OR= 2.031; IC : 1.160-3.554) (Table 7). Knowing that the general prevalence of overweight was low (10.3\%) (Table 5), and that Kaele city is a less urbanized area calling to become more urbanized, one can be afraid by the increased prevalence of weight gain and later HTN in this population in the upcoming years if nothing is done. Moreover, results also revealed an important number of prehypertensive participants (Table 4), although it is not yet the pathologic stage of the disease, it permits to identify those who are likely to progress to stage 1 , and needs preventive measurements to reduce the expansion of the disease (Zhang and Li, 2011). As such, the identification of specific risk factors for a population become important and the analysis of data (Table 7) shows some specificities for Kaele dwellers. Regarding the level of education, those with no education were 24.3 times at risk of HTN than those with a secondary level of education. These results corroborated those of Bovet et al. (2002) who also found higher rates of hypertensive subjects with low levels of education. Indeed, schooling would promote a better knowledge of the disease and the means to avoid it. Thus, the establishment of education and awareness programs could be a good mean of prevention. Marital status "married" increased the risk of hypertension by 3.1 times compared to "single" status. This situation could be partly due to age because most unmarried people were young. These results were contrary to those of Hawkley et al (2010) who shown a direct link between loneliness and systolic blood pressure. In addition, some studies (Twagirumukiza et al., 2011; Campbell et al., 2014) have shown that married people are less likely to be hypertensive than single people. However, a study conducted in South Africa showed that living in a marriage was negatively associated with HTN. It appears that among unmarried people, a reduction in the rating of HTN (OR = $0.30, \mathrm{p}<0.05$ ) was noted compared to the situation of married couples; while widows were associated with an increase in HTA odds $(\mathrm{OR}=2.43, \mathrm{p}<0.05)$. This could be due to the stress experienced by some married people since the association between stress and HTN has been proven. In fact, stress leads to a chronic increase in the secretion of catecholamine and cortisol resulting in a state of insulin resistance, visceral obesity, high levels of triglycerides and low levels of HDL-cholesterol associated with HTN (Hamer et al., 2008). In terms of age, individuals aged 30-39, 50-59 and 60 and older were respectively 4.1 times; 31.4 times and 18.7 times more exposed to high blood pressure than the younger ones (Table 7). These results were consistent with several prospective and observational surveys, which found a positive relationship between age and high blood pressure in a number of populations, regardless geographic, cultural and socio-economic characteristics as reported by Guimaraes (2002), who noted that among 25 to 34 years old, the rate of HTN ranged from 5.5 to $17.8 \%$, while among those aged 55 to 59 this rate rose to $41 \%$. The reduction of elasticity (increased rigidity) of large arteries is pointed out (Aronow et al., 2011) leading to endothelial dysfunction that develops over time and hence contributes to increased arterial stiffness in the elderly with isolated systolic HTN (Oparil et al., 2003).

No parameter of the food behavior investigated in this study significantly explained the occurrence of HTN in this population except the consumption of dairy products; those who did not consumed dairy products were twice as likely to be expose (Table 7). Indeed, calcium is one of the numerous nutrients responsible for the beneficial effect of dairy products on the control of blood pressure (KrisEtherton et al., 2009). Other minerals such as magnesium and potassium may also help regulate blood pressure, but their individual contributions are not easy to detect when present in calcium-rich foods (Xu et al., 2008). The most important effect could be attributed to bioactive peptide like casein, whose inhibitory effect on the angiotensin-1 converting enzyme has already been demonstrated in the process of controlling blood pressure (Rousseau-Ralliard et al., 2010; Ibrahim et al., 2017). Other studies have revealed that certain milk peptide derivatives also have hypotensive effects via endothelin 1 modulation, performed by the endothelial cell (German et al., 2009).

\section{CONCLUSION}

The present study suggests that Kaele populations were prone to HTN with a predominance of the systo-diastolic subtype. In addition, older age, male gender, abdominal fat accumulation, married individuals, low educational attainment, and low consumption of dairy products were the main risk factors for hypertension amongst population of this locality. As with undernutrition or nutrient deficiency problem, the implementation of programs against overnutrition related diseases becomes a need in the northern part of country. This will help to prevent the expansion of cardiovascular risk factors like hypertension the silent killer and then to solve the problem of double 
burden of malnutrition.

\section{Study limitations:}

A few number of participants and the absence of data related to salt consumption of these Kaele dwellers constituted the limitations of our study.

\section{Statement of Financial Disclosure :}

The authors report no specific funding in relation to this research and no conflicts of interest to disclose.

\section{Author Contributions:}

Study conception and design: NFR. Data collection and entering: FRN, MWN, BRTT, GD, OMM. Biochemical analysis: MWN, BRTT, OMM. Statistical analysis and interpretation: FRN, BGKA. Drafting FRN. Manuscript revision: JLN, EJO. All the authors approved the final version of the manuscript.

\section{REFERENCES}

Alberti KG, Zimmet P, Shaw J, Grundy SM; IDF Epidemiology Task Force Consensus Group (2006). The IDF Consensus worldwide definition of the metabolic syndrome. IDF.

Alberti KG, Zimmet P, Shaw J; IDF Epidemiology Task Force Consensus Group (2005). The metabolic syndrome a new worldwide definition. Lancet. 366:1059-1062

Aronow WS, Fleg JL, Pepine CJ, Artinian NT, Bakris G, Brown AS, Ferdinand KC, Forciea MA, Frishman WH, Jaigobin C, Kostis JB, Mancia G, Oparil S, Ortiz E, Reisin E, Rich MW, Schocken DD, Weber MA, Wesley DJ, Harrington RA(2011). ACCF Task Force ACCF/AHA 2011 expert consensus document on hypertension in the elderly: a report of the American College of Caridology Foundation Task Force on Clinical Expert Consensus Documents. Circulation. 123(21): 2434-2506.

Arrey WT, Dimala AC, Atashili J, Mbuagbaw JAJ, Monekosso GL (2016). Hypertension, an Emerging Problem in Rural Cameroon: Prevalence, Risk Factors, and Control. Int. J. Hypertens. 6: 1-6.

Azantsa KGB, Ntentie FR, Mbong AM-A, Kengne NAP, Kuaté D, Dakam W, Yangoua HCM, Ngondi LJ, Oben J (2013). Body Mass Index, Blood Pressure and Hypertension Subtypes among Untreated Hypertensive Cameroonians. Br. J. Med. Med. Res. 3(4): 2119-2131.

Azantsa KGB, Yangoua MCH, Ngondi JL, Oben JE (2010). The effect of body weight on the incidence and prevalence of hypertension in Yaoundé. J. Diabetes Endocrinol . 1(1): 006-012.

Bovet P, Burnier M, Madeleine G, Waeber B, Paccaud F (2002). Monitoring one-year compliance to antihypertension medication in the Seychelles. Bull World Health Organ 80 (1): 33-39.

Campbell NR, Nieylski M, Lackland D (2014). High blood pressure: why prevention and control are urgent and important. A fact sheet from the World Hypertension League and the International Society of Hypertension. J Clin Hypertens. 16: 551-553.

Cumber SN, Jaila S, Nancy B, Tsoka-Gwegweni MJ (2017). Under Five Malnutrition Crises in the Boko Haram Area of Cameroon. SAJCN. 30(2):41-42.

Dzudie A, Kengne A, Muna WFT, Ba H, Menanga A, kouam KC, Abah J, Monkam Y, Biholong C, Mintom P, Kamdem F, Djomou A, Ndjebet J, Wambo C, Luma H, Ngu KB, Kingue $S$ (2012). Prevalence, awareness, treatment and control of hypertension in a self-selected sub-Saharan African urban population: a cross-sectional study. BMJ Open.; 0:e001217.

Franklin SS, Pio JR, Wong ND, Larson MG, Leip EP, Vasan RS, Levy D (2005). Predictors of New-Onset Diastolic and Systolic Hypertension: The Framingham Heart study. Circulation. 111: 1121-1127.

German JB, Gibson RA, Krauss RM, Nestel P, Lamarche B, van Staveren WA, Steijns JM, de Groot LC, Lock AL, Destaillats F (2009). A reappraisal of the impact of dairy foods and milk fat on cardiovascular disease risk. Eur J Nutr. 48:191-203.

Ghadhban AHF, Habib OS (2011). A study of the distribution of blood pressure mesurements among university students. MJBU. 29 (1\&2): 43-50.

Gnindjio CNN, Hamadou B, Boombhi J, Essomba JPE, Kuate LM, Njouoguep RA, Ouankou NC, Amougou NS, Tankeu TA, Menanga PA, Kingue S (2018). Target Organ Damage in Newly Diagnosed Hypertensive Individuals in Yaoundé, Sub Saharan Africa. SM J Cardiolog and Cardiovasc Disord. 4(1): 1022.

Guimaraes AC (2002). Hypertension in Brazil. J Hum Hypertens. 16: 7 - 10.

Halperin RO, Sesso HD Ma, J, Buring JE, Stampfer MJ, Gaziano JM (2006). Dyslipidemia and the Risk of Incident Hypertension in Men. Hypertension. 47:45-50.

Hamer M, Molloy GJ, Stamatakis E (2008). Psychological distress as a risk factor for cardiovascular events: pathophysiological and behavioral mechanisms. J Am. Coll .Cardiol.; 52(25):2156-62

Hawkley LC, Thisted RA, Masi CM, Cacioppo JT (2010). Loneliness Predicts Increased Blood Pressure: Five-Year Cross-Lagged Analyses in Middle-Aged and Older Adults. Psychol Aging. 25(1): 132-141

Hendriks ME, Wit FWNM, Roos MTL, Brewster LM, Akande TM, De Beer IH, Mfinanga SG, Kahwa AM, Gatongi P, Van Rooy G, Janssens W, Lammers J, Kramer B, Bonfrer I, Gaeb E, van der Gaag J, Rinke de Wit TF, Lange JM, Schultsz C (2012). Hypertension in Sub-Saharan Africa: CrossSectional Surveys in Four Rural and Urban Communities. PLoS ONE. 7(3):e32638.

Hilliard LM, Mirabito KM, Denton KM (2013)a. Unmasking the potential of the AT (2) R: as a therapeutic target in hypertension in men and women: what we know and what we still need to find out. Clin Exp Pharmacol Physiol. 40: 542-550.

Hilliard LM, Sampson AK, Brown RD, Denton KM (2013)b. 
The "his and hers" of the renin-angiotansin system. Curr hypetens Rep. 15: 71-79.

Ibrahim HR, Ahmed AS, Miyata T (2017). Novel angiotensin-converting enzyme inhibitory peptides from caseins and whey proteins of goat milk. J. Adv. Res. 8, 6371

Kingue S, NdongNgoe C, Menanga A, Fesuh B, Nouedoui C, Muna WFT (2015). "Prevalence and risk factors of hypertension in urban areas of Cameroon: a nationwide population-based cross-sectional study". J Clin Hypertens. 17(10): 819-824.

Koopman W, Willems P, Smeitink J (2012). Mechanisms of disease: monogenic mitochondrial disorders. $\mathrm{N}$ Engl J Med. 366 (12): 1132-1141.

Kris-Etherton PM, Grieger JA, Hilpert KF, West SG (2009). Milk products, dietary patterns and blood pressure management. J Am Coll Nutr. 28 (1): 103S-119S

Lim SS, Vos T, Flaxman AD, Danaei G, Shibuya K, AdairRohani H, Amann M, Anderson HR, Andrews KG, Aryee M, Atkinson C, Bacchus LJ, Bahalim AN, Balakrishnan K, Balmes J, Barker-Collo S, Baxter A, Bell ML, Blore JD, Blyth F, Bonner C, Borges G, Bourne R, Boussinesq M, Brauer M, Brooks P, Bruce NG, Brunekreef B, Bryan-Hancock C, Bucello C, Buchbinder R, Bull F, Burnett RT, Byers TE, Calabria B, Carapetis J, Carnahan E, Chafe Z, Charlson F, Chen H, Chen JS, Cheng AT, Child JC, Cohen A, Colson KE, Cowie BC, Darby S, Darling S, Davis A, Degenhardt L, Dentener F, Des Jarlais DC, Devries K, Dherani M, Ding EL, Dorsey ER, Driscoll T, Edmond K, Ali SE, Engell RE, Erwin PJ, Fahimi S, Falder G, Farzadfar F, Ferrari A, Finucane MM, Flaxman S, Fowkes FG, Freedman G, Freeman MK, Gakidou E, Ghosh S, Giovannucci E, Gmel G, Graham K, Grainger R, Grant B, Gunnell D, Gutierrez HR, Hall W, Hoek HW, Hogan A, Hosgood HD 3rd, Hoy D, Hu H, Hubbell BJ, Hutchings SJ, Ibeanusi SE, Jacklyn GL, Jasrasaria R, Jonas JB, Kan H, Kanis JA, Kassebaum N, Kawakami N, Khang YH, Khatibzadeh S, Khoo JP, Kok C, Laden F, Lalloo R, Lan Q, Lathlean T, Leasher JL, Leigh J, Li Y, Lin JK, Lipshultz SE, London S, Lozano R, Lu Y, Mak J, Malekzadeh R, Mallinger L, Marcenes W, March L, Marks R, Martin R, McGale P, McGrath J, Mehta S, Mensah GA, Merriman TR, Micha R, Michaud C, Mishra V, Mohd Hanafiah K, Mokdad AA, Morawska L, Mozaffarian D, Murphy T, Naghavi M, Neal B, Nelson PK, Nolla JM, Norman R, Olives C, Omer SB, Orchard J, Osborne R, Ostro B, Page A, Pandey KD, Parry CD, Passmore E, Patra J, Pearce N, Pelizzari PM, Petzold M, Phillips MR, Pope D, Pope CA 3rd, Powles J, Rao M, Razavi H, Rehfuess EA, Rehm JT, Ritz B, Rivara FP, Roberts T, Robinson C, Rodriguez-Portales JA, Romieu I, Room R, Rosenfeld LC, Roy A, Rushton L, Salomon JA, Sampson U, Sanchez-Riera L, Sanman E, Sapkota A, Seedat S, Shi P, Shield K, Shivakoti R, Singh GM, Sleet DA, Smith E, Smith KR, Stapelberg NJ, Steenland K, Stöckl H, Stovner LJ, Straif K, Straney L, Thurston GD, Tran JH, Van Dingenen R, van Donkelaar A, Veerman JL, Vijayakumar L, Weintraub R, Weissman MM, White RA, Whiteford H, Wiersma ST, Wilkinson JD, Williams HC, William (2012). A comparative risk assessment of disease and injury attributable to 67 risk factors and risk factor clusters in 21 regions, 1990-2010: a systematic review analysis for the Global Burden of Disease Study. Lancet. 380: 22242260.

Lloyd-Jones D, Adams RJ, Brown TM, Carnethon M, Dai S (2010). Heart disease and stroke statistics--2010 update: a report from the American Heart Association. Circulation. 121(7):e46-215.

Maire B, Lioret S, Gartner A, Delpeuch F (2002). Transition nutritionnelle et maladies chroniques non transmissibles liées à l'alimentation dans les pays en développement. Cahiers d'études et de recherches francophones / Santé. 12 (1): 45-55

Mohsen IM, Damasceno A (2012). Hypertension in developing countries. Lancet. 380 (9841): 611-619.

Ndedi A (2017). Dealing with Food Insecurity with Improved Nutrition in the Far North Region of Cameroon (April 9, 2017). Humanistic Management Association, Research Paper Series No. 17-20.

Ntentie FR, Ngondi JL, Azantsa KBG, Santy EV, Dimodi HT, Mbong AM-A, Chakokam NRM, Nguimkeng SB, Zambou H, Oben EJ (2014). Urbanization and Metabolic Syndrome in Cameroun: Alertness on less urbanised areas. Endocrinol Metab Syndr. 3(2): 1-8.

Ogah OS, Rayner BL (2013). Recent advances in hypertension in sub-Saharan Africa. Heart. 99 (19) : 1390-1397.

Oparil S, Zaman MA, Calhoun DA (2003). Pathogenesis of hypertension. Ann Intern Med. 139: 761-776

Otsuka T, Takada H, Nishiyama Y, Kodani E, Saiki Y, Kato K, Kawada $\mathrm{T}$ (2016). Dyslipidemia and the Risk of Developing Hypertension in a Working-Age Male Population. J Am Heart Assoc. 5:e003053

Pancha MO, Adonis KK, Joachim C (2011). Hypertension and classical risk factors in ambulatory patients: A hospital-based study in Adamawa region (Northern Cameroon). Int. J. Med. Med. Sci. 3(11): 331-336.

Pancha MO, Derew D, Ngoufack TJ and Tangyi TM (2016). A Community-Based Assessment of Hypertension and Some Other Cardiovascular Disease Risk Factors in Ngaoundéré, Cameroon. Int J Hypertens. 1-9

Pancha MO, Ngoufack OJ, Koona KA, Maha F, Samuel K (2015). Place and Evolutionary Profile of Cardiovascular Diseases in Northern Cameroon: The Case of the Regional Hospital of Ngaoundere. Health Sciences and Disease. 16 (1): 1-7.

Rabarijaona LM, Rakotomalala DP, Rakotonirina EJ, Rakotoarimanana S, Randrianasolo $O$ (2009). Prevalence and severity of adult arterial hypertension in urban Antananarivo. Rev Anest Réa Méd Urg. 1 (4): 24-27.

Ramachandran A, Mary S, Yamuna A, Murugesan N, Snehalatha C (2008). High prevalence of diabetes and cardiovascular risk factors associated with urbanization in India. Diabetes Care. 31(5): 893-898.

Rousseau-Ralliard D, Goirand F, Tardivel S, Lucas A, Algaron $F$, Mollé $D$, Robert $V$, Auchère $D$, Boudier J-F, Gaillard J-L, Monnet V, Tauzin J, Grynberg A (2010). 
Inhibitory effect of $\alpha \mathrm{S} 1$ - and $\alpha \mathrm{S} 2$-casein hydrolysates on angiotensin I-converting enzyme in human endothelial cells in vitro, rat aortic tissue ex vivo, and renovascular hypertensive rats in vivo. J. Dairy Sci. $93: 2906-2921$

Seed AA, AI-Hamdan NA, Bahnassy AA, Abdalla AM, Abbas MAF, Abuzaid LF (2011). Prevalence, Awareness, Treatment, and Control of Hypertension among Saudi Adult Population: A National Survey. Int J Hypertens. 1-8.

Sliwa K, Stewart S, Gersh BJ (2011). Hypertension: A Global Perspective. Circulation. 123: 2892-2896.

Tanankem VB, Fotio AH (2016). Food Insecurity in Rural Households of Cameroon: Factors Associated and Implications for National Policies. PROCEEDINGS ICAS VII Seventh International Conference on Agricultural Statistics I Rome 24-26 October

Tebeu PM, Foumane P, Mbu R, Fosso G, Biyaga PT, Fomulu JN (2011). Risk Factors for Hypertensive Disorders in Pregnancy: A Report from the Maroua Regional Hospital, Cameroon. J Reprod Infertil. 12(3):227-234.

Twagirumukiza M, De Bacquer D, Kips JG, de Backer G, Stichele RV, Van Bortel LM (2011). Current and projected prevalence of arterial hypertension in sub-Saharan Africa by sex, age and habitat: an estimate from population studies. J. Hypertens. 29 (7):1243-1252.

World Health Organization (1996). The fight against hypertension. Series of technical reports. Report of a WHO Expert Committee, Geneva. No. 862.
World Health Organization (1999). Guidelines subcommette. 1999 World Health Organization-international society of hypertension guidelines for the management of hypertension. J. Hypertens. 17: 151-183.

World Health organization (2013). A global brief on Hypertension, Silent killer, global public health crisis. World Health Day 2013.

World Health Organization (2013). A global brief on Hypertension, Silent killer; global public health crisis. World Health Day.

World Health Organization (WHO)/International Society of Hypertension (ISH) (2003). Statement on management of hypertension. J. Hypertens. 21(11):1983-1992.

World Health Organization. WHO | World Health Statistics $2015 . \quad$ WHO. Available at:http://www.who.int/gho/publications/world_health_s tatistics/2015/en/ [visited on 02/02/2018].

Xu JY, Qin LQ, Wang PY, Li W, Chang C (2008). Effect of milk tripeptides on blood pressure: a meta-analysis of randomized controlled trials. J Nutr. 24: 933-940.

Xue B, Johnson AK, Hay M (2013). Sex differences in angiotansin II- and aldostérone-induced hypertension: the central protective effects of oestrogen. Am. J. Physiol. Regul. Integr. Comp. Physiol. 305: 459-463.

Zhang W, Li N (2011). Prevalence, Risk Factors, and Management of Prehypertension Int J Hypertens: 605359. 